\title{
The effect of a high protein diet on leucine and alanine turnover in acid maltase deficiency
}

\author{
A M UMPLEBY,* P StJ TREND, $\dagger$ D CHUBB, * J V CONAGLEN, * C D WILliAMS, * \\ R HESP,, I N SCOBIE,* C M WILES, $\dagger$ G SPENCER, $\ddagger$ P H SÖNKSEN*
}

From the Departments of Medicine, ${ }^{*}$ Neurology $\dagger$ and the Respiratory Unit, $\ddagger$ St Thomas' Hospital, and the Radioisotopes Division, $\S$ MRC Clinical Research Centre, Harrow, London, UK

SUMMARY Leucine and alanine production rate was measured in 5 patients with acid maltase deficiency in the postabsorptive state, following 6 months on a normal diet with placebo and 6 months on an isocaloric high protein diet (16-22\% protein). Whole body leucine production rate, a measure of protein degradation, expressed in terms of lean body mass was significantly greater than in five control subjects. Following the high protein diet, leucine production rate was decreased in four of the five patients but this was not statistically significant. Alanine production rate expressed in terms of lean body mass was significantly greater than in control subjects. After the high protein diet, alanine production rate and concentration were significantly decreased $(p<0.05)$. There were no significant improvements in any of the clinically relevant variables measured in these patients. It is possible that a larger increase in protein intake over a longer time period may have a clinical effect.

Type II glycogenosis (acid alpha-1,4-glucosidase deficiency) presents either in infancy, or in juvenile or adult forms.' Infants are floppy and develop gross cardiomegaly and hepatomegaly before perishing in the first few years of life. ${ }^{2}$ Adults tend to present in their late "teens or twenties with marked truncal and pelvic girdle weakness and impressive paraspinal muscle wasting. However, the key clinical feature is the presence of respiratory insufficiency which is chiefly caused by diaphragmatic weakness or paralysis. ${ }^{34}$ The diagnosis can be confirmed by finding absent or low levels of acid maltase in muscle, ${ }^{5}$ cultured skin fibroblasts ${ }^{6}$ and leucocytes. ${ }^{78}$

The muscle wasting and weakness in the adult-onset disease has been attributed to the disruption of muscle fibres caused by accumulation of glycogen in the sarcoplasm. ${ }^{9}$ Measurement of protein turnover in a patient with this disorder has demonstrated an increase in whole body protein degradation which suggests that the myopathy may be due to increased muscle breakdown. ${ }^{10}$ Treatment of the patient with a

Address for reprint requests: $\operatorname{Dr}$ A M Umpleby, Department of Medicine, UMDS, St Thomas' Hospital, London SE1 7EH, UK.

Present address of Dr J V Conaglen: Waikato Hospital, Hamilton, New Zealand.

Received 2 December 1988.

Accepted 22 March 1989 high protein diet for 7 months resulted in a decrease in whole body protein breakdown and a general improvement in the patient's condition. ${ }^{10}$ The beneficial effects of a high protein diet have also been reported in a child with this disorder " and in another? adult. ${ }^{12}$

The response of these patients to a high protein diet indicated the need for a more extensive study of the effects of increasing protein intake in acid maltase deficiency. We have, therefore, measured whole body protein turnover in five patients with acid maltase deficiency and examined the effect of 6 months of high protein diet.

\section{Methods}

Five patients (aged 42-50 yr) with adult onset acid maltase deficiency were recruited from the Respiratory Unit at St Thomas' Hospital. Clinical details of four of these patients have previously been reported. ${ }^{3}$ Details are shown in table 1 . All patients were studied (1) prior to therapeutic intervention, (2) after 6 months on an isocaloric high protein diet and (3) after 6 months on a placebo tablet. The selection of patients for the order of these two regimes was random. Patients 1, 4, 5, received the diet followed by the placebo study and patients 2,3 , the placebo study followed by the diet. On each occasion patients were admitted to a metabolic ward for seven days. The patients' normal dietary protein intake was assessed by a dietitian by keeping an accurate daily food diary for 1 week prior to the study. The subjects were encouraged to remain on their normal diet during the 
Table 1 Clinical details of acid maltase patients and control subjects

\begin{tabular}{|c|c|c|c|c|c|c|}
\hline $\begin{array}{l}\text { Acid Maltase } \\
\text { Patients }\end{array}$ & Sex & Age (yr) & $H t(\mathrm{~cm})$ & $W t(k g)$ & $\begin{array}{l}\% \text { Ideal } \\
\text { Body Weight }\end{array}$ & $\begin{array}{l}\text { Lean Body } \\
\text { Mass (kg) }\end{array}$ \\
\hline $\begin{array}{l}1 \\
2 \\
3 \\
4 \\
5 \\
\bar{x}, \text { SEM }\end{array}$ & $\begin{array}{l}\mathbf{M} \\
\mathbf{M} \\
\mathbf{F} \\
\mathbf{M} \\
\mathbf{M}\end{array}$ & $\begin{array}{l}42 \\
50 \\
43 \\
42 \\
43 \\
44,2\end{array}$ & $\begin{array}{l}193 \\
171 \\
172 \\
185 \\
176 \\
179,4\end{array}$ & $\begin{array}{l}84 \\
69 \\
53 \\
64 \\
61 \\
67,6\end{array}$ & $\begin{array}{c}100 \\
103 \\
83 \\
82 \\
87 \\
91,10\end{array}$ & $\begin{array}{l}32 \\
28 \\
28 \\
27 \\
27,4\end{array}$ \\
\hline $\begin{array}{l}\text { Control subjec } \\
1 \\
2 \\
3 \\
4 \\
5 \\
\bar{x}, \text { SEM }\end{array}$ & $\begin{array}{l}\text { rnove } \\
\mathbf{M} \\
\mathbf{M} \\
\mathbf{F} \\
\mathbf{M} \\
\mathbf{M}\end{array}$ & $\begin{array}{l}34 \\
43 \\
52 \\
35 \\
44 \\
42,3\end{array}$ & $\begin{array}{l}188 \\
179 \\
165 \\
178 \\
183 \\
179,4\end{array}$ & $\begin{array}{l}84 \\
93 \\
70 \\
83 \\
74 \\
81,4\end{array}$ & $\begin{array}{r}104 \\
126 \\
116 \\
115 \\
98 \\
112,11\end{array}$ & $\begin{array}{l}65 \\
62 \\
42 \\
60 \\
57 \\
57,4\end{array}$ \\
\hline $\begin{array}{l}\text { Control subjec } \\
1 \\
2 \\
3 \\
4 \\
\bar{x}, \text { SEM }\end{array}$ & $\begin{array}{l}\text { Irnove } \\
\text { M } \\
\text { F } \\
\text { F } \\
\text { F }\end{array}$ & $\begin{array}{l}38 \\
57 \\
31 \\
25 \\
38,7\end{array}$ & $\begin{array}{l}188 \\
177 \\
172 \\
174 \\
178,4\end{array}$ & $\begin{array}{l}80 \\
81 \\
65 \\
63 \\
72,5\end{array}$ & $\begin{array}{r}100 \\
117 \\
100 \\
95 \\
103,10\end{array}$ & $\begin{array}{l}63 \\
49 \\
47 \\
48 \\
52,4\end{array}$ \\
\hline
\end{tabular}

Table 2 Dietary composition of the acid maltase patients during the placebo and the high protein diet

\begin{tabular}{|c|c|c|c|c|c|}
\hline Patient & Carbohydrate $(\mathrm{g})$ & Protein (g) & Fat $(g)$ & Total calories & $\begin{array}{l}\% \text { Calories } \\
\text { from protein }\end{array}$ \\
\hline $\begin{array}{l}\text { a Normal diet } \\
1 \\
2 \\
3 \\
4 \\
5\end{array}$ & $\begin{array}{l}387 \\
248 \\
266 \\
284 \\
159\end{array}$ & $\begin{array}{l}94 \\
74 \\
65 \\
97 \\
74\end{array}$ & $\begin{array}{r}111 \\
75 \\
99 \\
127 \\
97\end{array}$ & $\begin{array}{l}3008 \\
1952 \\
2320 \\
2373 \\
2155\end{array}$ & $\begin{array}{l}12 \cdot 5 \\
15 \cdot 0 \\
11 \cdot 2 \\
16 \cdot 3 \\
13 \cdot 6\end{array}$ \\
\hline $\begin{array}{l}\text { b High protein diet } \\
1 \\
2 \\
3 \\
4 \\
5\end{array}$ & $\begin{array}{l}359 \\
252 \\
267 \\
207 \\
101\end{array}$ & $\begin{array}{r}117(24 \%) \\
87(18 \%) \\
105(62 \%) \\
155(60 \%) \\
88(19 \%)\end{array}$ & $\begin{array}{r}141 \\
88 \\
110 \\
128 \\
61\end{array}$ & $\begin{array}{l}3032 \\
2119 \\
2423 \\
2790 \\
1432\end{array}$ & $\begin{array}{l}15 \cdot 4 \\
16 \cdot 3 \\
17 \cdot 3 \\
22 \cdot 2 \\
22 \cdot 3\end{array}$ \\
\hline
\end{tabular}

The percentage increase in protein intake is shown in parentheses.

initial assessment and whilst on the placebo. During the diet treatment phase patients were asked to increase the proportion of calories provided by protein to $25 \%$ of their total caloric intake. None of the patients were able to do this but all, except one, were able to increase the proportion of calories taken as protein by $6 \%$, one subject managed an increase of over $9 \%$ (table 2 ). This protein intake was maintained during their assessment in the metabolic ward. Twenty four hour urine samples were collected on days 4,5 and 6 of the admission period for measurement of creatinine. Blood samples were taken to measure metabolites, amino acids, insulin, growth hormone, creatinine kinase and creatinine. During each admission measurements were made of leucine turnover, alanine turnover, oral glucose tolerance and lean body mass. Clinical assessment of the patients was undertaken by a blind observer and included measurement of the maximum voluntary isometric knee extension force, the time to walk 30 metres and the time to walk up and down 10 steps, erect and supine vital capacity, maximal static ins- piratory and expiratory mouth pressures, ${ }^{13}$ the trans-diaphragmatic pressure, ${ }^{14}$ estimates of cardiac output determined from echocardiogram tracings and the maximum oxygen utilisation rate. Measurements of leucine and alanine metabolism were also made in two separate groups of control subjects on their usual caloric intake. Details of sex, age, weight, height and body mass are shown in table 1 .

The patients and control subjects gave informed written consent. The study was approved by the Ethical Committee of St Thomas' Hospital, the Isotope Advisory Panel of the Medical Research Council and the Department of Health and Social Security.

Leucine and alanine turnover were measured the morning after an overnight fast. Thirty minutes after cannulation of an antecubital vein for blood sampling, a rapid injection of $0.93 \mathrm{MBq}(25 \mu \mathrm{Ci})\left[1-{ }^{14} \mathrm{C}\right]$ leucine and $2.8 \mathrm{MBq}(75 \mu \mathrm{Ci})$ $\left[3-{ }^{3} \mathrm{H}\right]$ alanine (Radiochemical Centre, Amersham, England) was administered into a contralateral antecubital vein. Blood samples were taken immediately before the injection of the 
isotopic tracers for baseline measurements, then every minute to 5 minutes, at 8 and 10 minutes, then at every 10 minutes to 120 minutes. Collections of expired air for measurement of ${ }^{14} \mathrm{CO}_{2}$ and $\% \mathrm{CO}_{2}$ were made at intervals over the 2 hour period via a 2-way valve into Douglas Bags every 4 minutes to 20 minutes and every 10 minutes thereafter. Inspiratory volume was measured by a Wright Respirometer (British Oxygen Company, Harlow, England) attached to the inspiratory end of the 2-way valve.

An oral glucose tolerance test was performed the morning after an overnight fast. Following ingestion of $100 \mathrm{~g}$ glucose, blood samples were taken over a 2 hour period for the measurement of plasma glucose and insulin.

Total body potassium (TBK) measured by whole body counting of potassium- 40 was used to estimate lean body mass (LBM). ${ }^{\text {is }}$ Normal values of TBK for the control subjects were calculated from equations based on weight, height and age. ${ }^{16}$

${ }^{14} \mathrm{C}$ leucine and ${ }^{3} \mathrm{H}$ alanine were measured on $1.5 \mathrm{ml}$ plasma samples as described previously. ${ }^{17}$ Plasma glucose was measured on a Clandon Scientific glucose analyser (Yellow Springs Instrument Company, USA). Blood ketones, pyruvate, lactate and glycerol were determined enzymatically. ${ }^{18}$ Plasma non-esterified fatty acids were extracted and measured using standard methods. ${ }^{20}{ }^{21}$ Insulin and growth hormone were measured by radioimmunoassay ${ }^{22}$ and urinary creatinine was measured by the Jaffe reaction on an autoanalyser.

Plasma leucine and alanine activity curves $(\mathrm{dpm} / \mathrm{ml})$ were fitted with the sum of three exponentials using a least squares error optimisation algorithm. ${ }^{23}$ Leucine and alanine metabolic clearance rates (MCR) were calculated from the area under their respective activity curves. $\begin{aligned} & \text { Leucine or alanine } \\ & \mathrm{MCR}(\mathrm{ml} / \mathrm{min} / \mathrm{kg})\end{aligned}=$

$\frac{\text { Injected dose of tracer }(\mathrm{dpm} / \mathrm{kg})}{\text { Area under activity curve }(\mathrm{dpm} / \mathrm{ml} \times \mathrm{min})}$

Leucine and alanine turnover (or production rate, $\mu \mathrm{mol} /$ $\mathrm{min} / \mathrm{kg}$ ) were then calculated by multiplying MCR by concentration. Leucine oxidation rate was calculated using a model of leucine metabolism which includes a bicarbonate subsystem (fig l) as previously described. ${ }^{17}$ The parameters for the leucine subsystem model were calculated in each subject from the three exponential equations describing the leucine specific activity curve. The parameters for $k_{42}$ and the bicarbonate subsystem were determined by a process of adaptive fitting minimising the sum of squares error between model derived and experimental $\mathrm{CO}_{2}$ specific activity curve. ${ }^{17}$ Leucine oxidation rate was then calculated from the following equation:

Leucine oxidation rate $(\mu \mathrm{mol} / \mathrm{min} / \mathrm{kg})=$

$$
\frac{\mathbf{k}_{42}\left(\min ^{-1}\right)}{\mathbf{k}_{42}+\mathbf{k}_{\mathrm{p} 2}\left(\min ^{-1}\right)} \times \begin{aligned}
& \text { leucine turnover } \\
& (\mu \mathrm{mol} / \mathrm{min} / \mathrm{kg})
\end{aligned}
$$

where $k_{42}$ is the rate constant for leucine oxidation and $k_{p 2}$ the rate constant for leucine incorporation into protein as shown in fig 1 . The rate of leucine incorporation into protein was calculated from leucine turnover minus leucine oxidation rate.

The levels of statistical significance for differences between values for control subjects and the acid maltase patients were calculated using Student's $t$ test. A paired $t$ test was used to calculate the significance of differences between the placebo and treatment studies in the acid maltase patients. For each

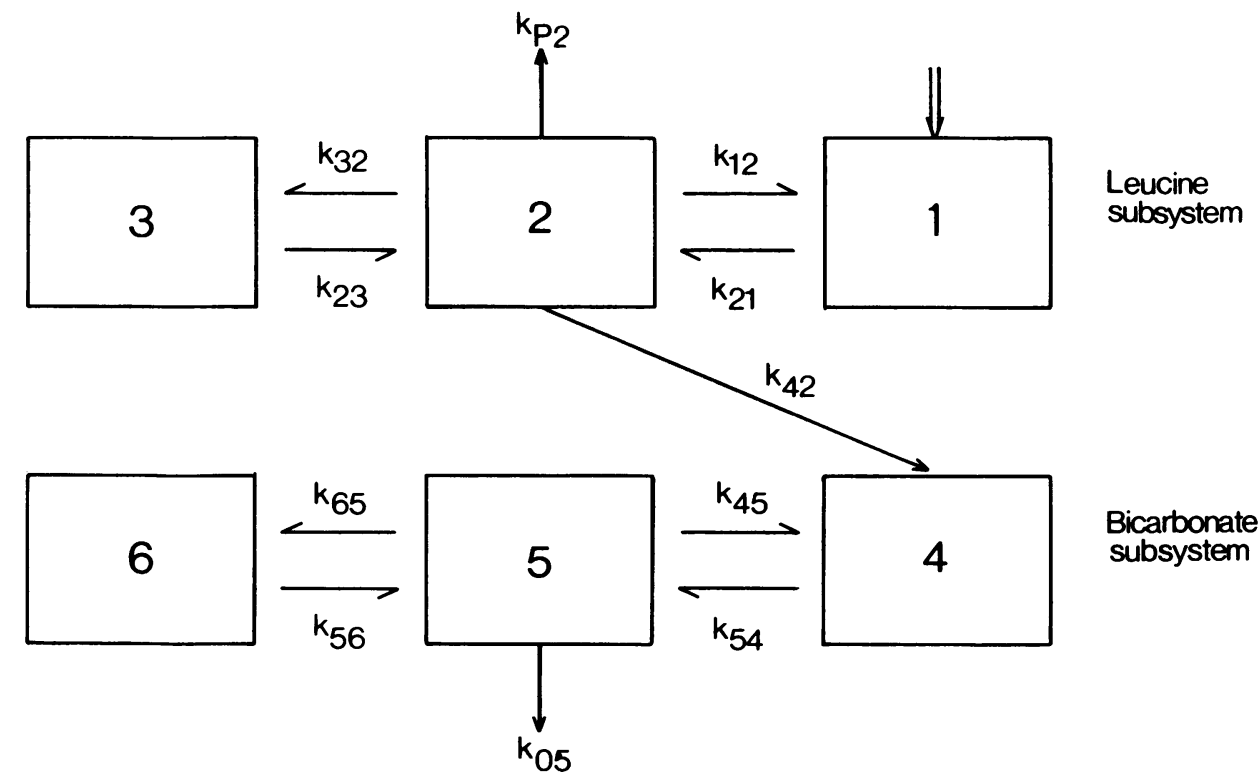

Fig 1 Compartmental model of leucine and bicarbonate metabolism. The single arrows represent the direction of flux between compartments or out of the system. The double arrow indicates the site of injection. 
Table 3 Measurements of blood metabolites, insulin and $C$ peptide $(\bar{x}, S E M)$ in the acid maltase patients and control subjects)

\begin{tabular}{|c|c|c|c|c|}
\hline & \multicolumn{3}{|c|}{ Acid maltase patients $(n=5)$} & \multirow[b]{2}{*}{ Control subjects $\dagger(n=5)$} \\
\hline & Baseline & Placebo & Diet & \\
\hline $\begin{array}{l}\text { Acetoacetate }(\mathrm{mmol} / \mathrm{l}) \\
\text { B Hydroxybutyrate }(\mathrm{mmol} / \mathrm{l}) \\
\text { Pyruvate }(\mathrm{mmol} / \mathrm{l}) \\
\text { Lactate }(\mathrm{mmol} / \mathrm{l}) \\
\text { Glycerol }(\mathrm{mmol} / \mathrm{l}) \\
\text { FFA }(\mathrm{mmol} / \mathrm{l}) \\
\text { Glucose }(\mathrm{mmol} / \mathrm{l}) \\
\text { Insulin }(\mathrm{uU} / \mathrm{ml}) \\
\text { C peptide }(\mathrm{nmol} / \mathrm{l})\end{array}$ & $\begin{array}{c}0 \cdot 06,0 \cdot 04 \\
0 \cdot 19,0 \cdot 13 \\
0 \cdot 04,0 \cdot 01 \\
0 \cdot 84,0 \cdot 18^{*} \\
0 \cdot 13,0 \cdot 04 \\
0 \cdot 63,0 \cdot 10 \\
5 \cdot 40,0 \cdot 54 \\
17 \cdot 27,7 \cdot 70 \\
0 \cdot 54,0 \cdot 18\end{array}$ & $\begin{array}{c}0.07,0.02 \\
0 \cdot 14,0.04 \\
0.07,0 \cdot 01 \\
0 \cdot 83,0 \cdot 08^{*} \\
0 \cdot 12,0 \cdot 03 \\
0 \cdot 92,0 \cdot 10 \\
5 \cdot 42,0 \cdot 15 \\
14 \cdot 10,6 \cdot 59 \\
0.61,0 \cdot 13\end{array}$ & $\begin{array}{c}0.09,0.03 \\
0 \cdot 18,0.06 \\
0.07,0.01 \\
0 \cdot 82,0 \cdot 08^{*} \\
0 \cdot 16,0 \cdot 02 \\
0 \cdot 71,0 \cdot 03 \\
5 \cdot 42,0 \cdot 31 \\
12 \cdot 90,5 \cdot 41 \\
0 \cdot 54,0.08\end{array}$ & $\begin{array}{l}0.05,0.07 \\
0 \cdot 05,0.01 \\
0.04,0.01 \\
0 \cdot 58,0.05 \\
0 \cdot 19,0.03 \\
0 \cdot 51,0.05 \\
5 \cdot 12,0.22 \\
4 \cdot 58,1.01 \\
0.52,0.04\end{array}$ \\
\hline
\end{tabular}

*Significantly different from control subjects $\mathrm{p}<0.05$.

†Leucine turnover study.

clinical assessment the differences between the values following the high protein diet and the values following the placebo were plotted as histograms and the distribution shown to be normal.

\section{Results}

As shown in table 1 , all of the acid maltase patients studied were within $20 \%$ of their ideal body weight. However, the lean body mass of all the patients was significantly lower $(p<0.05)$ than in a group of age and height matched normal subjects (table 1). Body weight and lean body mass did not alter following the high protein diet or placebo study.

In the fasting state lactate concentrations were significantly greater $(p<0.05)$ in the acid maltase patients than in the control subjects but the means of other metabolite measurements were normal (table 3 ). Fasting insulin concentrations, although normal in patients 1,4 and 5, were elevated in patient $2(34 \mu \mathrm{U} /$ $\mathrm{ml})$ and patient $3(14 \mu \mathrm{U} / \mathrm{ml})$ and were not affected by either the diet or the placebo treatment.

The response of plasma glucose, insulin and $\mathrm{C}$ peptide to an oral glucose tolerance test (OGTT) is shown in fig 2 . Two patients [2 and 3] were within WHO criteria for impaired glucose tolerance, ${ }^{24}$ two patients [4 and 5] displayed borderline impaired glucose tolerance and patient 1 was normal. Patient 2 had a raised fasting glucose of $6.4 \mathrm{mmol} / \mathrm{l}$ and a very high insulin response to the OGTT suggesting that this patient was insulin resistant. The response of $\mathrm{C}$ peptide to the oral glucose paralleled that of insulin in each case, the ratio of insulin to $\mathrm{C}$ peptide being unusually high in patient 2 . The high protein diet and placebo treatment had no effect on the response to an OGTT in each patient (data not shown).

Fasting leucine concentration was significantly lower in the acid maltase patients $(p<0.05)$ than in the control subjects in the baseline study and after six months of placebo or high protein diet (table 4). In the baseline study and after 6 months of placebo study,


Fig 2 Glucose insulin and C-peptide concentrations in the 5 acid maltase deficient patients following a $100 \mathrm{~g}$ oral glucose tolerance test. The shaded area indicates the normal range. 
leucine metabolic clearance rate (MCR), production rate $(\mathrm{Ra})$ and the rate of leucine incorporation into protein were not significantly different from the subjects when expressed in terms of whole body control weight. However, when expressed in terms of lean body mass, these measurements of leucine metabolism were significantly greater $(p<0.05)$ than normal (table 4). Although there were no statistically significant changes in these measurements of leucine metabolism following the high protein diet, plasma leucine, $\mathrm{Ra}, \mathrm{MCR}$ and the rate of leucine incorpora- tion into protein were all reduced in 4 of the 5 patients $[1,3,4$ and 5] as shown in fig 3 .

Alanine MCR and production rate expressed as lean body mass were significantly greater $(p<0.05)$ than the controls in the baseline study and following the placebo (table 5). As shown in fig 3, alanine MCR was lower in four of the patients after the high protein diet than after the placebo. Alanine production rate and concentration (table 5) was reduced in all five patients by high protein therapy $(p<0.05)$.

Urinary creatinine excretion in the acid maltase

Table 4 Measurements of leucine metabolism $(\bar{x}, S E M)$ in the acid maltase patients and control subjects, expressed in terms of body weight ( $B W$ ) and lean body mass ( $L B M$ )

\begin{tabular}{|c|c|c|c|c|c|}
\hline & & \multicolumn{3}{|c|}{ Acid Maltase Patients $(n=5)$} & \multirow[b]{2}{*}{ Control subjects $(n=5)$} \\
\hline & & Baseline & Placebo & Diet & \\
\hline $\begin{array}{l}\text { Leucine MCR } \\
(\mathrm{ml} / \mathrm{min} / \mathrm{kg}) \\
\text { Leucine Ra } \\
(\mu \mathrm{mol} / \mathrm{min} / \mathrm{kg}) \\
\text { Leucine oxidation } \\
(\mu \mathrm{mol} / \mathrm{min} / \mathrm{kg}) \\
\text { Rate of leucine } \\
\text { incorporation into } \\
\text { protein }(\mu \mathrm{mol} / \mathrm{min} / \mathrm{kg})\end{array}$ & $\begin{array}{l}\text { BW } \\
\text { LBM } \\
\text { BW } \\
\text { LBM } \\
\text { BW } \\
\text { LBM } \\
\text { BW } \\
\text { LBM }\end{array}$ & $\begin{array}{l}14 \cdot 7,3 \cdot 04 \\
38 \cdot 6,5 \cdot 10^{*} \\
1 \cdot 38,0 \cdot 35 \\
3 \cdot 36,0 \cdot 85^{*} \\
0 \cdot 15,0 \cdot 04 \\
0 \cdot 34,0 \cdot 08 \\
1 \cdot 24,0 \cdot 11 \\
3 \cdot 04,0 \cdot 32^{*}\end{array}$ & $\begin{array}{l}14 \cdot 75,2 \cdot 84 \\
35 \cdot 75,13 \cdot 28^{*} \\
1 \cdot 37,0 \cdot 22 \\
3 \cdot 29,0 \cdot 32^{*} \\
0 \cdot 21,0 \cdot 08 \\
0 \cdot 49,0 \cdot 16 \\
1 \cdot 20,0 \cdot 14 \\
2 \cdot 80,0 \cdot 23^{*}\end{array}$ & $\begin{array}{l}13 \cdot 55,2 \cdot 70 \\
33 \cdot 41,6 \cdot 28^{*} \\
1 \cdot 16,0 \cdot 12^{*} \\
2 \cdot 88,0 \cdot 29 \\
0 \cdot 14,0 \cdot 03 \\
0 \cdot 34,0 \cdot 01 \\
1 \cdot 02,0 \cdot 10^{*} \\
2 \cdot 51,0 \cdot 23\end{array}$ & $\begin{array}{l}11 \cdot 69,0.89 \\
16.47,1 \cdot 16 \\
1.66,0.15 \\
2 \cdot 33,0.13 \\
0.20,0.02 \\
0.27,0.03 \\
1.46,0.12 \\
2 \cdot 05,0.11\end{array}$ \\
\hline Leucine concentration $(\mu \mathrm{mol} / \mathrm{l})$ & & $95,12^{*}$ & $95,7^{*}$ & $89,7 *$ & 136,8 \\
\hline
\end{tabular}

*Significantly different from control subjects $p<0.05$.

Placebo Diet
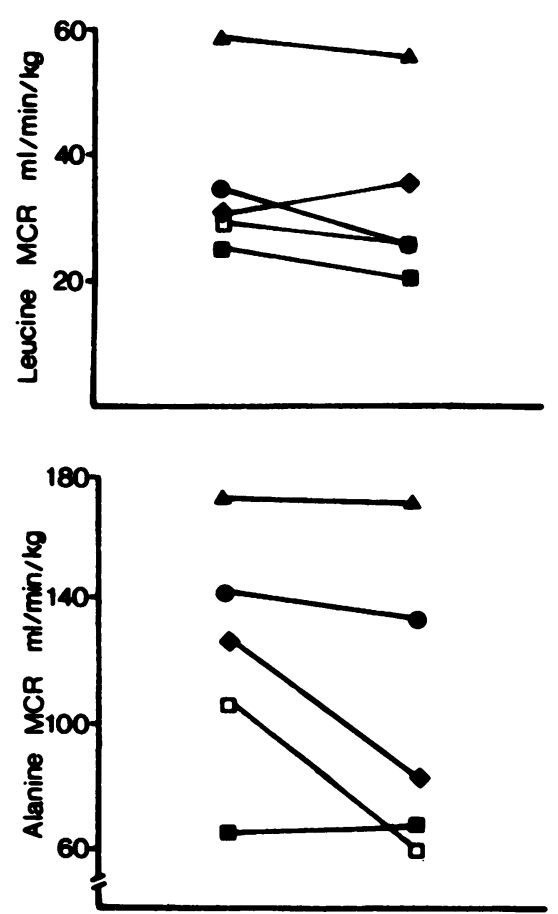

Placebo

Diet
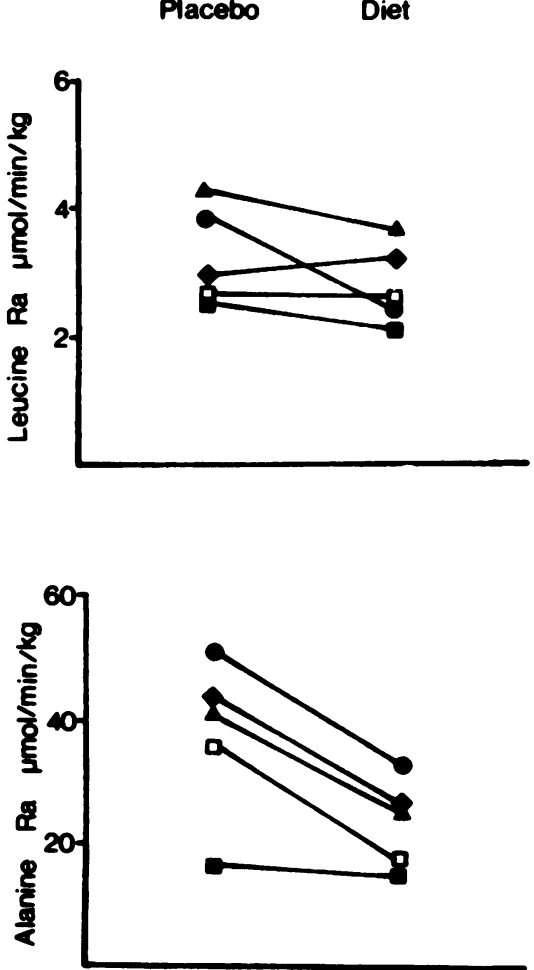

Fig 3 Leucine and alanine metabolic clearance rate (MCR) and leucine and alanine production rate $(\mathrm{Ra})$ following 6 months' treatment with a placebo and 6 months' on a high protein diet. 
Table 5 Measurements of alanine metabolism ( $\bar{x}, S E M)$ in the acid maltase patients and control subjects, expressed in terms of body weight ( $B W$ ) and lean body mass ( $L B M)$

\begin{tabular}{|c|c|c|c|c|c|}
\hline & & \multicolumn{3}{|c|}{ Acid Maltase Patients $(n=5)$} & \multirow[b]{2}{*}{ Control subjects $(n=4)$} \\
\hline & & Baseline & Placebo & Diet & \\
\hline $\begin{array}{l}\text { Alanine MCR } \\
(\mathrm{ml} / \mathrm{min} / \mathrm{kg}) \\
\text { Alanine } \mathrm{Ra} \\
(\mu \mathrm{mol} / \mathrm{min} / \mathrm{kg}) \\
\text { Alanine concentration }(\mu \mathrm{mol} / \mathrm{l})\end{array}$ & $\begin{array}{l}\text { BW } \\
\text { LBM } \\
\text { BW } \\
\text { LBM }\end{array}$ & $\begin{array}{l}40 \cdot 23,5 \cdot 4 \\
102 \cdot 05,11 \cdot 6 \dagger \\
11 \cdot 78,2 \cdot 62 \\
27 \cdot 21,3 \cdot 79 \dagger \\
283,27\end{array}$ & $\begin{array}{l}50 \cdot 8,9 \cdot 3 \\
122 \cdot 0,16 \cdot 4 \dagger \\
15 \cdot 8,3 \cdot 0 \\
38 \cdot 0,6 \cdot 0 \dagger \\
306,46\end{array}$ & $\begin{array}{r}42 \cdot 2,10 \cdot 4 \\
101 \cdot 2,20 \cdot 7 \\
9 \cdot 3,1 \cdot 7^{*} \\
22 \cdot 8,3 \cdot 4^{*} \\
237,24^{*}\end{array}$ & $\begin{array}{l}42 \cdot 1,3 \cdot 8 \\
59 \cdot 3,6 \cdot 8 \\
9 \cdot 9,1 \cdot 2 \\
13 \cdot 7,1 \cdot 2 \\
247,48\end{array}$ \\
\hline
\end{tabular}

*Significantly different from placebo $p<0.05$

†Significantly different from control $\mathrm{p}<0.05$.

Table 6 Mean difference between treatment and placebo period in the clinical assessments of the patients

\begin{tabular}{|c|c|c|c|c|c|}
\hline Category & No patients assessed & Mean & $S E$ mean & \multicolumn{2}{|c|}{$95 \%$ confidence limits } \\
\hline $\begin{array}{l}\text { Quadriceps strength }(\mathrm{N}) \\
\text { Timed } 30 \mathrm{~m} \text { walk (S) } \\
\text { Timed } 10 \text { steps up/down }(\mathrm{S}) \\
\text { VC fall }(\mathrm{l}) \\
\mathrm{Pi}_{\max }\left(\mathrm{cm} . \mathrm{H}_{2} \mathrm{O}\right) \\
\mathrm{Pdi}\left(\mathrm{cm} . \mathrm{H}_{2} \mathrm{O}\right) \\
\mathrm{CO}(\mathrm{l} / \mathrm{min}) \\
\text { VO } \max (\mathrm{l} / \mathrm{min}) \\
\mathrm{CK}(\mathrm{iv} / \mathrm{l})\end{array}$ & $\begin{array}{l}5 \\
4 \\
3 \\
5 \\
4 \\
3 \\
5 \\
3 \\
5\end{array}$ & $\begin{array}{l}0.6 \\
1.3 \\
-0.3 \\
0.14 \\
1.8 \\
1.7 \\
-0.6 \\
-0.003 \\
-5.0\end{array}$ & $\begin{array}{l}3 \cdot 3 \\
1 \cdot 6 \\
1 \cdot 0 \\
0 \cdot 29 \\
3 \cdot 1 \\
4 \cdot 6 \\
0 \cdot 7 \\
0 \cdot 18 \\
29 \cdot 0\end{array}$ & $\begin{array}{l}-8 \cdot 7 \\
-3 \cdot 8 \\
-4 \cdot 6 \\
-0.68 \\
-8 \cdot 0 \\
-18 \cdot 0 \\
-2 \cdot 5 \\
-0.79 \\
-86.0\end{array}$ & $\begin{array}{l}9 \cdot 9 \\
6 \cdot 3 \\
3 \cdot 9 \\
0 \cdot 96 \\
12 \cdot 0 \\
22 \cdot 0 \\
1 \cdot 3 \\
0 \cdot 78 \\
76 \cdot 0\end{array}$ \\
\hline
\end{tabular}

patients was significantly lower in the baseline study $(5 \cdot 1,0 \cdot 6, \bar{x}$, SEM) than in the control subjects $(12 \cdot 3$, $0.7)(p<0.05)$ and showed no significant change after the placebo and high protein diet.

There was no significant difference between treatment with a high protein diet and treatment with a normal diet plus a placebo tablet, in any of the clinical assessments. The numbers of patients in whom complete data were available, the mean differences, the standard errors of the mean differences and the values representing $95 \%$ confidence limits are presented in table 6. The maximum benefit of a high protein diet consistent with these data may be gleaned from inspection of the $95 \%$ confidence limit values. As examples, on the basis of these data, a high protein diet could not be expected to produce more than an increase of 10 Newtons in maximal isometric knee extension force, more than an increase of $12 \mathrm{~cm}_{\text {in }} \mathrm{H}_{2} \mathrm{O}$ in maximal static inspiratory mouth pressure or more than a fall of $86 \mathrm{U} / \mathrm{l}$ in creatinine kinase.

\section{Discussion}

The adult onset form of acid maltase deficiency is a rare disease and we were fortunate to be able to recruit five patients for the study. As a result of the small number of patients, differences in leucine and alanine metabolism between patients and control subjects and in response to the high protein diet were not always clear cut.

Although four of the five patients studied were of apparently normal weight for their height, their lean body mass (fat free mass) was reduced to almost half that of normal. Therefore when comparing measurements of amino acid turnover in these patients with normal subjects it may be important to express measurements in terms of lean body mass rather than body weight. When expressed in terms of lean body mass, leucine production rate, a measure of whole body protein degradation, and the rate of leucine incorporation into protein, a measure of whole body protein synthesis, were significantly greater than in the control subjects. Since tissues other than muscle are not clinically affected in acid maltase deficiency this suggests that the muscle wasting in this disorder is due to an increase in muscle protein breakdown.

Damage to muscle tissue as a result of disruption of lysosomes releasing glycogen and autolytic enzymes may result in loss of intracellular amino acids. Protein breakdown may, therefore, increase to preserve the intracellular amino acid pool with a compensatory increase in synthesis. ${ }^{25}$ This is unlike the muscle wasting in Duchenne muscular dystrophy ${ }^{26}$ and cancer cachexia $^{27}$ which has been shown to be the result of a decrease in protein synthesis. Increased protein degradation, however, has been reported in muscle 
wasting due to skeletal trauma and burn injury. 2829

In a previous study, in a single patient with this disease, we also reported an increase in protein degradation expressed in terms of lean body mass which was decreased by treatment with a high protein diet. This was accompanied by a clinical improvement of the patient. ${ }^{10}$ In the present study, we were not able to demonstrate a significant reduction in whole body protein degradation or significant improvements in any of the clinically relevant variables measured following 6 months' treatment with a high protein diet. Protein degradation, however, was lower, after the diet, in four out of the five patients studied. It is therefore possible that a higher protein intake and a longer study period is necessary for a significant clinical effect and a significant decrease in protein turnover to be demonstrated.

The failure of a high protein diet to reduce proteolysis in patient 2 may be due to the patient being "insulin resistant". This may have reduced amino acid uptake following a meal since the uptake of branched chain amino acids has been shown to be reduced in obese patients in whom insulin resistance is a well known feature; ${ }^{30}$ alternatively, since Patient 2 was only able to increase his protein intake from $15 \%$ to $16.3 \%$ of his total caloric intake this may have been insufficient to produce a detectable effect.

If a high protein diet has an inhibitory effect on protein turnover in acid maltase deficiency, this is contrary to the effect of increased protein intake in normal subjects. There is an increase in protein synthesis and a decrease in protein breakdown following feeding in normal subjects and this response is greater when protein intake is increased. In the postabsorptive state, however, protein breakdown is increased with a high protein intake. ${ }^{31}$ In the acid maltase patients any inhibitory effect of the high protein diet on protein breakdown during feeding appears to be maintained in the postabsorptive state.

Measurement of alanine turnover using $\left[3-{ }^{3} \mathrm{H}\right]$ alanine should approximate the absolute rate of in vivo transamination since the ${ }^{3} \mathrm{H}$ is removed during or after alanine transamination. ${ }^{32}$ Alanine turnover was lower after the diet than after the placebo which suggests the diet reduced the rate of transamination and the rate of alanine production. Since leucine production rate was reduced in four of the five patients a small proportion of the fall in alanine production in these patients can be accounted for by the decrease in proteolysis. However, most of the decrease must be due to reduced de novo alanine synthesis. A decrease in alanine flux, measured with $\mathrm{L}-\left[3,3,3,-{ }^{2} \mathrm{H}_{3}\right]$ alanine, in response to a high protein diet has previously been reported in normal subjects, whereas restricting protein intake was shown to increase flux..$^{33}$ It was proposed that these changes in alanine flux were due to the resultant changes in carbohydrate intake with these diets, that is decreased carbohydrate with the high protein diet and increased carbohydrate with the restricted protein intake. Although this could provide an explanation for the decrease in alanine production rate in three of the acid maltase patients, carbohydrate intake was unchanged in two patients. It is therefore more likely that there was a direct effect of protein intake on alanine turnover in these patients.

Abnormal glucose tolerance has been reported in other muscle wasting diseases such as myotonic dystrophy $^{34}$ and amyotrophic lateral sclerosis. ${ }^{35}$ It has previously been reported as normal in acid maltase deficiency. ${ }^{1012}$ It is unclear why abnormal glucose tolerance was not found in all patients and why the degree of intolerance varied from patient to patient. Although there was no direct relationship between the amount of muscle wasting and the degree of glucose intolerance the patient with the normal OGTT had the highest lean body mass. It is possible that the response to an OGTT may be related to the proportion of muscle and fat in these patients since the rate of peripheral uptake by muscle and fat are the factors which determine the late phase of the plasma glucose curve. ${ }^{36}$

Contrary to previous studies which have investigated the effect of a high protein diet in singlo patients, a high protein diet was found to have n\& clinical effect in the present study. Measurement 8 protein turnover, however, demonstrated a decrease ic protein catabolism in all but one patient who was found to be insulin resistant. Unfortunately we were only able to recruit five patients for this study and it may well be that the small numbers involved and the limited duration of the study in relation to the lifelong nature of this condition accounted for our failure to show a more clear and beneficial effect. It is possible that over a longer time period and with a larger increase in protein intake a more marked effect may be demonstrable.

We thank Miss $\mathrm{C}$ Isles for dietary management, Miss $L$ Beckwith for her technical assistance, $\operatorname{Dr} M$ Boroujerdi for mathematical analysis of the data, Mrs L Lawrence for help with the manuscript, colleagues at the Clinical Research Centre where TBK measurements were performed, and the British Diabetic Association and St Thomas' Hospital Endowment Committee for funding this research.

\section{References}

1 Engel AG, Gomez MR, Seybold ME, Lambert EH. The spectrum and diagnosis of acid maltase deficiency. Neurology 1973;23:95-106. 
2 Di Mauro S. Metabolic myopathies. In: Vinken PJ, Bruyn GW, eds. Handbook of Clinical Neurology Vol 41. Amsterdam: North Holland, 1980:174.

3 Trend P StJ, Wiles CM, Spencer GT, Morgan-Hughes JA, Lake BD, Patrick AD. Acid maltase deficiency in adults: diagnosis and management in five cases. Brain 1985;108:845-60.

4 Keunen RWM, Lambregts PCLA, Op de Coul AAW, Joosten EMG. Respiratory failure as initial symptom of acid maltase deficiency. $J$ Neurol Neurosurg Psychiatry 1984;47:549-52.

5 Angelini C, Engel AG. Comparative study of acid maltase deficiency: biochemical differences between infantile, childhood and adult types. Arch Neurol 1972;26:344-9.

6 Angelini C, Engel AG, Titus JL. Adult acid maltase deficiency: abnormalities in fibroblasts cultured from patients. N Eng J Med 1972;287:948-51.

7 Dreyfus JC, Poenaru L. Alpha glucosidases in white blood cells, with reference to the detection of acid alpha-1,4-glucosidase deficiency. Biochem Biophys Res Commun 1978;85:615-22.

8 Shankse S, Di Mauro S. Late-onset acid maltase deficiency: biochemical studies of leukocytes. $J$ Neurolog Sci 1981;50:57-62.

9 Hudgson P, Fulthorpe JJ. The pathology of type II skeletal muscle glycogenosis. $J$ Pathol 1975;116: 139-47.

10 Umpleby AM, Wiles CM St J, Trend P, et al. Protein turnover in acid maltase deficiency before and after treatment with a high protein diet. J Neurol Neurosurg Psychiatry 1987;50:587-92.

11 Slonim AE, Coleman RA, McElligot MA, et al. Improvement of muscle function in acid maltase deficiency by high protein therapy. Neurology 1983;33:34-8.

12 Isaacs $H$, Savage $\mathbf{N}$, Badenhorst $M$, Whistler T. Acid maltase deficiency: a case study and review of the pathophysiological changes and proposed therapeutic measures. J Neurol Neurosurg Psychiatry 1986; 49:1011-8.

13 Black LE, Hyatt RE. Maximal static respiratory pressures in generalised neuromuscular disease. Am Rev Resp Dis 1971;103:641-50.

14 Agostini E, Rahn H. Abdominal and thoracic pressures at different lung volumes. J Appl Physiol 1960:15: 1087-92.

15 Smith T, Hesp R, Mackenzie J. Total body potassium calibration for normal and obese subjects in two types of whole body counter. Physiology in Medicine and Biology 1979;24:171-5.

16 Boddy K, King PC, Hume R, Weyers E. The relation of total body potassium to height, weight and age in normal adults. J Clin Pathol 1972;25:512-7.

17 Umpleby AM, Brown PM, Boroujerdi MA, Carson ER, Sönsken PH. The effect of metabolic control on leucine metabolism in Type 1 (insulin dependent) diabetic patients. Diabetologia 1986;29:131-41.

18 Williamson DH, Mellanby J, Krebs HA. Enzymic determination of $\mathrm{D}(-)$ hydroxybutyrate acid and acetoacetic acid in blood. Biochemistry 1962;82:90-6.

19 Hohorst HJ, Kreutz FH. Bucher Uber Metaboltgehalte und metabolit-konzentrationen in der leber der ratte. Biochemische Zeitschrift 1959;332:18-46.

20 Dole VP, Meinhertz H. Microdetermination of longchain fatty acids in plasma and tissues. $\mathrm{J} \mathrm{Biol} \mathrm{Chem}$ 1960;235:2595-9.

21 Carruthers M, Young DAB. Free fatty acid estimation by a semi-automated fluorimetric method. Clin Chim Acta 1973;49:341-8.

22 Sönsken PH. Double antibody technique for the simultaneous assay of insulin and growth hormone. In: Antoniades HN, ed. Hormones in Human Blood: Detection and Assay. London: Harvard University Press, 1976.

23 Marquardt DW. An algorithm for least squares estimation of non-linear parameters. Journal of Social Industrial Applied Mathematics. 1963;11:431-41.

24 World Health Organisation Expert Committee on Diabetes Mellitus 2nd Report (1980).

25 Rennie MJ. Muscle protein turnover and the wasting due to injury and disease. Br Med Bull 1985;41:257-64.

26 Rennie MJ, Edwards RHT, Millward DJ, Wolman SL, Halliday D, Matthews DE. Effects of Duchenne muscular dystrophy on muscle protein synthesis. Nature 1982;296:165-7.

27 Emery PW, Edwards RHT, Rennie MJ, Souhani RK, Halliday D. Protein synthesis in muscle measured in vivo in cachetic patients with cancer. $\mathrm{Br} M e d \mathrm{~J}$ 1984;289:584-6.

28 Birkhahn RH, Long CL, Fitkin D, Dyger JW, Blakemore WS. Effects of major skeletal trauma on whole body protein turnover in man measured by $\mathrm{L}-\left[{ }^{14} \mathrm{C}\right]$ leucine. Surgery 1980;88:294-9.

29 Kien CL, Young VR, Rohrbaugh DK, Burke JF. Increased rates of whole body synthesis and breakdown in children recovering from burns. Ann Surg 1978;187:383-91.

30 Forlani G, Vannini P, Marchesini G, Zoli M, Ciavarella A, Pisi E. Insulin-dependent metabolism of branchedchain amino acids in obesity. Metabolism 1984;33 147-50.

31 Motil KJ, Matthews DE, Bier DM, Burke JF, Munro HN, Young VR. Whole body leucine and lysine metabolism: response to dietary protein intake in young men. Am J Physiol 1981;240:E712-21.

32 Yang RD, Matthews DE, Bier DM, Lo C, Young VR. Alanine kinetics in humans: influence of different isotopic tracers. Am J Physiol 1984;247:E634-8.

33 Yang RD, Matthews DE, Bier DM, Wen ZML, Young VR. Response of alanine metabolism in humans to manipulation of dietary protein and energy intakes. Am J Physiol 1984;250:E39-46.

34 Bjorntonp P, Schroder G, Ornhdahl G. Carbohydrate and lipid metabolism in relation to body composition in myotonic dystrophy. Diabetes 1977;22:238-42.

35 Steinke J, Tyler HR. The association of amyotrophic lateral sclerosis (motor neuron disease) and carbohydrate intolerance; a clinical study. Metabolism 1964;13:1376-81.

36 Moxley RT, Griggs RC, Forbes GB, Goldblatt D, Donohoe $\mathrm{K}$. Influence of muscle wasting on oral glucose tolerance testing. Clin Sci 1983;64:601-9. 